This article was downloaded by: [National Taiwan University]

On: 15 September 2008

Access details: Access Details: [subscription number 788846425]

Publisher Taylor \& Francis

Informa Ltd Registered in England and Wales Registered Number: 1072954 Registered office: Mortimer House, 37-41 Mortimer Street, London W1T 3JH, UK

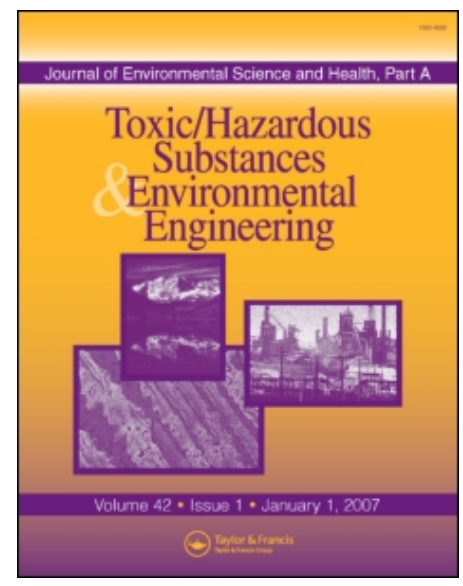

Journal of Environmental Science and Health, Part A

Publication details, including instructions for authors and subscription information:

http://www.informaworld.com/smpp/title content=t713597268

\title{
A SIMPLE MODELING APPROACH TOWARDS HYDROPERIOD EFFECTS ON FISH DYNAMICS IN A NORTHERN TAIWAN WETLAND ECOSYSTEM
}

Chung-Min Liao a; Jeng-Wei Tsai a; Ming-Chao Lin ${ }^{b}$

a Department of Agricultural Engineering, National Taiwan University, Taipei, Taiwan, ROC ${ }^{\mathrm{b}}$ Institute of Zoology, Academia Sinica, Taipei, Taiwan, ROC

Online Publication Date: 31 July 2001

To cite this Article Liao, Chung-Min, Tsai, Jeng-Wei and Lin, Ming-Chao(2001)'A SIMPLE MODELING APPROACH TOWARDS HYDROPERIOD EFFECTS ON FISH DYNAMICS IN A NORTHERN TAIWAN WETLAND ECOSYSTEM',Journal of Environmental Science and Health, Part A,36:7,1205 - 1226

To link to this Article: DOI: $10.1081 /$ ESE-100104872

URL: http://dx.doi.org/10.1081/ESE-100104872

\section{PLEASE SCROLL DOWN FOR ARTICLE}

Full terms and conditions of use: http://www.informaworld.com/terms-and-conditions-of-access.pdf

This article may be used for research, teaching and private study purposes. Any substantial or systematic reproduction, re-distribution, re-selling, loan or sub-licensing, systematic supply or distribution in any form to anyone is expressly forbidden.

The publisher does not give any warranty express or implied or make any representation that the contents will be complete or accurate or up to date. The accuracy of any instructions, formulae and drug doses should be independently verified with primary sources. The publisher shall not be liable for any loss, actions, claims, proceedings, demand or costs or damages whatsoever or howsoever caused arising directly or indirectly in connection with or arising out of the use of this material. 
J. ENVIRON. SCI. HEALTH, A36(7), 1205-1226 (2001)

\title{
A SIMPLE MODELING APPROACH TOWARDS HYDROPERIOD EFFECTS ON FISH DYNAMICS IN A NORTHERN TAIWAN WETLAND ECOSYSTEM
}

\author{
Chung-Min Liao, ${ }^{1, *}$ Jeng-Wei Tsai, ${ }^{1}$ and Ming-Chao Lin $^{2}$ \\ ${ }^{1}$ Department of Agricultural Engineering, National Taiwan \\ University, Taipei, Taiwan 10617 ROC \\ ${ }^{2}$ Institute of Zoology, Academia Sinica, Taipei, Taiwan 11529 ROC
}

\begin{abstract}
In this paper we develop a simple dynamic model to describe the seasonality of fish population subjected to the pattern of water level fluctuations (i.e., hydroperiod) in a northern Taiwan wetland ecosystem, Kuandu Natural Reservation. We use a harmonic oscillation to characterize hydroperiod quantitatively by obtaining the amplitude and timing of the dominant periodic component in a time series of water levels. The model illustrates the temporal pattern of fish dynamics through the year that can result in very high density of fish at the end of a hydroperiod as well as the importance of ponds and other depressions that both are refuges and sinks during dry periods. We suggest that a 9-mon effective threshold in the length of the hydroperiod must be exceeded to produce high fish population densities. Our results also indicate that the large, piscivorous fish appear to have a major impact on smaller fish in the marsh habitat. Simulation results reveal that the recovery of small fish populations in the marsh following a major drought requires up to two years. The collective results imply that human activities such as drainage or other alterations of the hydrology can exacerbate natural cycles and results in detrimental stresses on fish production and the higher trophic levels dependent on this production.
\end{abstract}

\footnotetext{
*Corresponding author. E-mail: cmliao@ccms.ntu.edu.tw
} 
Key Words: Dynamic model; Ecosystem; Fish; Hydroperiod; Wetland.

\section{INTRODUCTION}

Fluctuating marsh ecosystems are found throughout the tropics and subtropics, but their fish population dynamics are little understood. In Taiwan region, for example, such marshes seasonal variation in rainfall and discharge cause considerable variation in the depth and extent of water cover, and many of these marshes become dry each year. Kushlan $(1,2)$, Capone and Kushlan (3), and Jordan et al. (4) pointed out that the seasonal water level cycle appears to be the dominant influence on the fish community. During the usual dry down, marsh fish become densely concentrated in ponds, but little is known about population fluctuations of the fish during the rest of the year outside the ponds.

The pattern of water level fluctuations in a wetland is its hydroperiod. Periodic draughts can amplify the effects of the annual dry season and result in the drying of freshwater marsh. This produces massive losses of fish numbers and threatens the residual seed populations of fish needed to repopulate the marshes in the next wet season. Snodgrass et al. (5) indicated that hydroperiod accounted for significant portions of variation in controlling the bioavailability of $\mathrm{Hg}$ in a wetland ecosystem. Lorenz (6) revealed that sites with a longer hydroperiod had a higher density in fish biomass than sites with a shorter hydroperiod. One of the factors helping to mitigate the severity of the effects of drought is the quasi-permanent water bodies that are refuges for fish during these dry down. Fish that can locate refuges during dry downs may survive the most severe droughts.

These quasi-permanent water bodies, however, are not guaranteed sanctuaries for fish that move into them. Crowding can lead to oxygen depletion and higher susceptibility to disease. In addition, the larger water bodies typically house many piscine reptilian predators. For small fish, the most significant predators may be the large size fish. Thus, the fraction of small fish that fish survive a dry down will be the product of the fraction of fish that move into water bodies deep enough to last through the dry down and the fraction of those that escape mortality from predation and crowding in these refuges.

In view of the likelihood that conditions amenable to the maintenance of a healthy wetland ecosystem are likely to worsen over years in Taiwan. Moreover, because of human interference, there is now concern about the current functioning of this system of biological energy collection and concentration in the most freshwater marsh in Taiwan region. Wading bird numbers and reproductive have declined. The system of levees and canals built in the neighbor of wetlands to divert water for urban and agricultural water use and flood control has altered the natural hydrological cycles over large portions of the wetland region, and has reduced the formerly high availabilities 
of fish for the wading birds over much of this landscape. Thus, the system of water regulation has imposed a stress on the natural functioning of the system.

So far the manner and extent of the restoration have not yet been defined. A key part of the prediction is how various proposed hydrologic restoration alternatives will affect fish population across the landscape. Each alternative will involve a partial return to natural conditions but will unavoidable retain much of the present system of dikes and canals. Snodgrass et al. (7) indicated that hydroperiod length should be included as a primary criterion in wetland regulations. Jordan et al. (4) recommended that resource managers consider using fish as indicator to evaluate the efficacy of ongoing restoration and management efforts in wetland systems.

To understand causes of hydroperiod seasonality on fish dynamics, a simple dynamic model is developed. The model describes a hypothetical wetland designed according to literature data supplemented by unpublished data on Kuandu, a wetland ecosystem in the northern Taiwan region. The primary object of this paper is to describe the effect of water level changes on population levels of fish in the marshes on both seasonal and long-term basis. We focus on the seasonal dynamics of the community of small fish (e.g., mosquitofish (Gambusia affinis) and silverbiddy (Gerres abbreviatus)) as water level change through the year. This small fish are major prey items for many wading birds in Kuandu wetland ecosystem.

This paper predicts the effects of prolonged droughts on fish populations that have become more frequent during the past few decades of human intervention. A lengthy period of drought may reduce remnant populations of fish to very low levels and the recovery for the populations after the drought may be correspondingly low. The potential for large piscivorous fish to have a regulatory effect on the smaller fish that are important to the wading birds is also examined.

\section{MODEL STRUCTURE}

\section{Hydroperiod Dynamics}

Nuttle (8) has been successfully used the harmonic analysis in measuring wetland hydroperiod. With the quantitative measures of hydroperiod derived by harmonic analysis, he was able to demonstrate statistically the relationship between water management and hydroperiod. In this paper, we use a simple harmonic oscillation to characterize hydroperiod by obtaining the amplitude and timing of dominant periodic component in a time series of water level (8),

$$
y=\bar{y}+A \cos \left[2 \pi\left(\frac{d-d_{\max }}{365}\right)\right],
$$


where $y$ is the water depth in the cell during the year (m), $\bar{y}$ is the mean water depth (m), $A$ is the amplitude of the water depth cycle, $d$ is the day of the year (d), and $d_{\max }$ is the day of the year on which water depth is a maximum.

\section{Lower Trophic Dynamics}

It generally assumes that the ultimate limits on the growth of the fish populations can be determined by the lower trophic levels represented by periphytons, macrophytes, mesoinvertebrates, macroinvertebrates, and detritus that are resources of the fish.

The dynamic model corresponding to the graphic model of Figure 1 describing the lower trophic interactions can be expressed by considering from the aspect of traditional predator-prey model that is known as the Lotka-Volterra model as (9),

$$
\frac{d B_{1}(t)}{d t}=a B_{1}(t)-b B_{1}^{2}(t)-c\left(d B_{4}(t)+e B_{5}(t)\right) B_{1}(t)-\alpha B_{1}(t),
$$

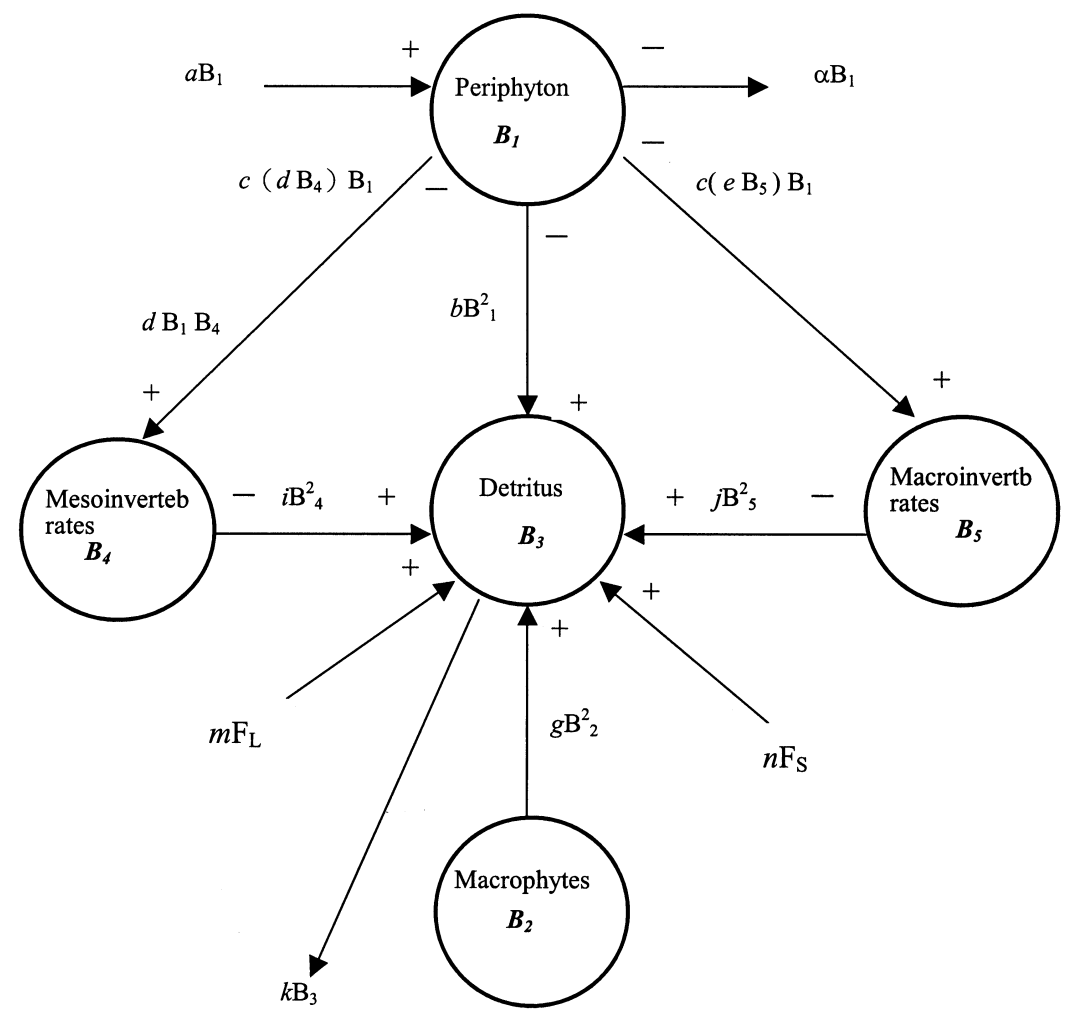

Figure 1. Lower trophic interactions among periphyton, macrophytes, macroinvertebrates, mesoinvertebrates and detritus. 


$$
\begin{aligned}
\frac{d B_{2}(t)}{d t}= & f B_{2}(t)-g B_{2}^{2} \\
\frac{d B_{3}(t)}{d t}= & h\left(b B_{1}^{2}(t)+g B_{2}^{2}(t)+i B_{4}^{2}(t)+j B_{5}^{2}(t)\right) \\
& -k B_{3}^{2}(t)+m F_{L}(t)+n F_{S}(t) \\
\frac{d B_{4}(t)}{d t}= & d B_{1}(t) B_{5}(t)-i B_{4}^{2}(t) \\
\frac{d B_{5}(t)}{d t}= & e B_{1}(t) B_{5}(t)-j B_{5}^{2}(t)
\end{aligned}
$$

where $B_{1}$ is the periphyton biomass $(\mathrm{g}), B_{2}$ is the macrophyte biomass $(\mathrm{g}), B_{3}$ is the detrital biomass $(\mathrm{g}), B_{4}$ is the mesoinvertebrate biomass (those $<1 \mathrm{mg}$ body weight), $B_{5}$ is the macroinvertebrate biomass (those $>1 \mathrm{mg}$ body weight), $F_{L}$ is the large fish biomass $(\mathrm{g})$, and $F_{S}$ is the small fish biomass (g). The following parameters may be seasonally varying: $a$ is the periphyton growth rate $\left(\mathrm{d}^{-1}\right), b$ is the periphyton death rate $\left(\mathrm{d}^{-1} \mathrm{~g}^{-1}\right), c$ is the inverse of assimilation rate of macroinvertebrates and mesoinvertebrates (dimensionless), $d$ is the mesoinvertebrate growth rate $\left(\mathrm{d}^{-1} \mathrm{~g}^{-1}\right), e$ is the macroinvertebrate growth rate $\left(\mathrm{d}^{-1} \mathrm{~g}^{-1}\right), f$ is the macrophyte growth rate $\left(\mathrm{d}^{-1}\right), g$ is the macrophyte death rate $\left(\mathrm{d}^{-1} \mathrm{~g}^{-1}\right), h$ is the percentage production in detritus (dimensionless), $i$ is the mesoinvertebrate death rate $\left(\mathrm{d}^{-1} \mathrm{~g}^{-1}\right), j$ is the macroinvertebrate death rate $\left(\mathrm{d}^{-1} \mathrm{~g}^{-1}\right), k$ is the detritus decay rate $\left(\mathrm{d}^{-1} \mathrm{~g}^{-1}\right), m$ is the large fish death rate $\left(\mathrm{d}^{-1}\right), n$ is the small fish death rate $\left(\mathrm{d}^{-1}\right)$, and $\alpha$ is the small fish periphyton uptake rate $\left(\mathrm{d}^{-1}\right)$.

An underlying assumption of Eq. [2] is that the lower trophic interactions between predators and prey consist of a single predator consuming a single prey item.

\section{Fish Life Cycles}

Most of the fish that have been found in Kuandu wetland include mosquitofish (Gambusia affinis), silverbiddy (Gerres abbreviatus), large-scale mullet (Liza marcolepis), jarbua terapon (Terapon jarbua), broadhead sleeper (Eleotris melanosoma) and euryhaline teleost (Oreochomis sp.) (10). In the model, two fish functional types are categorized according to the body length, the small planktivorous functional type (e.g., G. affinis and T. jarbua, body length ranged from $18-32 \mathrm{~mm}$ ) and the large piscivorous functional type (e.g., L. marcolepis and $O$. mossambicus, body length ranged from 59-274 mm).

The fish in each of these two functional types are modeled as 1-mon ageclass. Growth in age, growth in size, and mortality occurs on a 3-d time step 
basis, but an increase to the next age-class occurs only on the first time step within a given month. Thus the age of fish in days $(t)$ may be expressed as,

$$
t=30 m+m_{d},
$$

where $m$ represents the month age-class of a particular fish and $m_{d}$ is the day of the month.

Gamito (11) suggested that for seasonal growth for long-lived fish, the von Bertalanffy equation is preferable to describe fish population growth and mortality. We thus use the von Bertalanffy equation to calculate the size of the fish in a particular $m$-mon age-class as,

$$
L_{m}=L_{\infty}\left(1-e^{k\left(t-t_{0}\right)}\right),
$$

where $L_{m}$ is the fish size in a $m$-mon age-class, whereas weight in grams dry weight is given by the weight-length relationship,

$$
W=\alpha L^{\beta},
$$

where $L_{\infty}, k, t_{0}, \alpha$, and $\beta$ are constants. It is assumed that all fish that survive through a given time step grow at the growth rate specified by Eqs. [4] and [5].

Mature fish of each functional group produce a number of viable offspring during their reproductive season. The age of maturity, the fecundity, and the months during the year in which each functional group reproduces are specified as input data.

Four types of mortality assumptions are embodied in the model: (i) The natural mortality of an uncrowded population which is dependent on individual fish size class, but is independent of population size. The agedependent functional form for survival used in this model is assumed by the equations that have been taken from the ecological literature and all have been used in modeling real situations (9),

$$
S(t)=1.0-\frac{p_{1}}{1+\left(p_{2} t\right)^{p_{3}}},
$$

where $S(t)$ is the survival rate at the age of fish $t$, whereas $p_{1}, p_{2}$, and $p_{3}$ are constants; (ii) Density-dependent mortality due to starvation. This is calculated by first computing the density of preferred prey for a particular ageclass of a particular functional group. As this density of preferred prey decreases, the mortality rate of that specific age-class and functional group increases; (iii) Losses due to predation from the other functional group in the model is also included. Particularly, fish of the small functional type are preyed on by the fish of the large functional type. Predation from wading birds is not yet included in this model; and (iv) Losses due to drying out of a spatial cell. 


\section{Movement Patterns}

A scenario that would lead to the movement patterns of fish in the Kuandu wetland ecosystem may occur if the hydroperiod dynamics is considered to be the only environmental driving variable. The movement patterns that coupled water level fluctuations and fish population that the model attempts to capture in the hypothetical wetland designed according to Kuandu landscape can be described as follows.

When the water depth in the spatial cell falls to low levels, the fish begin to move to depressions or ponds. The large fish move first and the smallest fish last. All have moved to depressions before the depth relative to the surface of the cell falls to zero. Some fraction of the fish present in the spatial cell at each time is allocated either to ponds or to depressions. The fractions of each species that reach ponds or depressions, respectively, can be specified.

As the water level drops further, the portion of a cell area that remains under water diminishes. Only the deeper depressions remain flooded. We assume that the fish can move to the depressions, but that some fraction will reach only shallower, isolated depressions and become stranded as water levels continue to fall. If depressions dry out, or are discovered by wading birds, the fish in them are lost from the population. Those surviving in depressions emerge into the cell when the water level rises again.

\section{Trophic Dynamics}

The small-fish functional type is assumed to feed only on lower trophiclevel materials, whereas the large-fish functional type undergoes a shift from small prey (taken from lower trophic levels) to fish of the small-fish functional type. On each time step, surviving fish of each functional type and ageclass are assumed to grow in length by an amount specified by Eq. [5]. This results in an increase in weight as

$$
\Delta W=W_{t}-W_{t-3}=\alpha L_{t}^{\beta}-\alpha L_{t-3}^{\beta},
$$

for each fish. This biomass must be acquired through predation. Thus it is assumed that on each time step an amount of biomass of $\sum_{i} \Delta W / c$ is removed from the prey species in the model, where the summation index, $i$, runs over all fish and $c$ is the biomass conversion efficiency of the predator in converting consumed prey into predator offspring.

Each predator may have its preferred prey. Both the small fish functional type and the smaller size classes of the large-fish functional type prefer meso- and macro-invertebrates, whereas the larger size classes of the large piscivorous fish functional type prefer the smaller fish. 


\section{MODEL IMPLEMENTATIONS}

\section{Input Parameters}

Simulations of the model were preformed to examine the following general aspects on the behavior of the fish populations: (i) the dynamics of the fish population in the marsh through a year as a function of the hydroperiod, and (ii) the effect of droughts of various duration on the survival of fish in the marsh and on their recovery after the water depths return to previous levels. The simulations results were include the following: (i) numbers of fish per square meter (summed over age-classes) for each functional group at monthly intervals, and (ii) biomass of fish for each functional group in the study area on monthly intervals. Input parameters for the model simulation are described as follows.

Study area: The study area was chosen in the northern Taiwan wetland, Kuandu Natural Reservation where a shallow marsh 0.5-1 m deep in the wet season. During the typical dry season the marsh dries and water becomes confined to ponds. We chose a spatial cell measuring $1000 \mathrm{~m} \times 1000 \mathrm{~m}$ as our basic landscape unit. This size is arbitrary, yet large enough that an entire landscape, such as the Kuandu wetland, could be modeled as a grid of cells.

Fish life cycle parameters: The values of fish growth parameters in Eqs. [4] and [5] are presented in Table 1. Table 1 also gives the values of the age of maturity, the fecundity, and the months during the year where each functional group reproduces. Table 2 lists the range values of reproduction parameters for each month.

Table 1. Values of Principal Life Cycle Parameters

\begin{tabular}{lcc}
\hline & \multicolumn{2}{c}{ Fish Functional Type } \\
\cline { 2 - 3 } Parameter & Type 1: Small Fish & Type 2: Large Fish \\
\hline von Bertalanffy coefficients $^{\mathrm{a}}$ & 5.0 & \\
$\mathrm{~L}_{\infty}$ & -6.0 & 40.0 \\
$\mathrm{~K}$ & 0.045 & -6.0 \\
$t_{0}$ & & 0.0175 \\
Weight-length coefficients $^{\mathrm{b}}$ & 0.0013 & 0.0015 \\
$\alpha$ & 3.73 & 3.24 \\
$\beta$ & 30.0 & 360.0 \\
Age of maturity (d) & $\mathrm{c}$ & 10.0 \\
Fecundity, number offspring per month, per fish $^{\mathrm{c}}$ & 20.0 & Jan.-Oct. \\
Months where reproduction occurs $^{\mathrm{c}}$ & Feb.-Nov. \\
\hline
\end{tabular}

${ }^{\mathrm{a}}$ Adapted from Gamito [11].

${ }^{\mathrm{b}}$ For small fish, the values are based on the large-scale mullet $\left(\mathrm{r}^{2}=0.95\right)$, whereas for large fish, euryhaline teleost is adopted $\left(r^{2}=0.94\right)$ in curve fitting to Eq. (5).

${ }^{\mathrm{c}}$ Adapted from Shao [10]. 
Mortality parameters: The parameters in Eq. [6] of the age-dependent functional form for the mortality were chosen to roughly fit estimated survival curves of the two functional fish groups based on literature data from Kushlan $(1,2)$. The resulting fitting parameters are listed in Table 3 . The other three mortality parameters account for density-dependent mortality due to starvation, losses due to predation from other functional group, and losses due to drying out of a spatial cell, are lumped as a bulk parameter according to literature data adapted from Kennth and Timothy (12) and Werner et al. (13). Table 4 gives the lumped mortality parameters in each month.

Movement patterns parameters: The fractions of each species that reach ponds during dry down and moving from pond to marsh during reflooding in each corresponding month are specified shown in Table 5. These values given in Table 5 are estimated from the literature data adapted from McIvor and Odum (14) and Jordan and et al. (4). They are based on observations in the field, but little quantitative evidence exists to support them at present.

Table 2. Reproduction Parameters in Each Month for Two Functional Type Fish ${ }^{\mathrm{a}}$

\begin{tabular}{lcc}
\hline & \multicolumn{2}{c}{ Fish Functional Type } \\
\cline { 2 - 3 } Month & Type 1: Small Fish & Type 2: Large Fish \\
\hline Jan. & 1 & $1.15 \sim 1.2$ \\
Feb. & 1 & $1.15 \sim 1.2$ \\
March & $1.01 \sim 1.2$ & $1.1 \sim 1.2$ \\
April & $1.005 \sim 1.25$ & $1.1 \sim 1.25$ \\
May & $1.01 \sim 1.35$ & $1.15 \sim 1.6$ \\
June & $1.1 \sim 1.5$ & $1.2 \sim 1.8$ \\
July & $1.25 \sim 1.55$ & $1.7 \sim 1.8$ \\
Aug. & $1.35 \sim 1.6$ & $1.75 \sim 1.85$ \\
Sept. & $1.45 \sim 1.7$ & $1.5 \sim 1.8$ \\
Oct. & $1.5 \sim 1.7$ & $1.2 \sim 1.35$ \\
Nov. & $1.4 \sim 1.6$ & 1.3 \\
Dec. & 1.2 & 1 \\
\hline
\end{tabular}

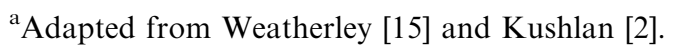

Table 3. Parameters Used in Density-Dependent and Age-Specified Survival Rate in Eq. (6) ${ }^{\mathrm{a}}$

\begin{tabular}{lcc}
\hline & \multicolumn{2}{c}{ Fish Functional Type } \\
\cline { 2 - 3 } Parameter & Type 1: Small Fish & Type 2: Large Fish \\
\hline$p_{1}$ & 0.8 & 0.6 \\
$p_{2}$ & 0.05 & 0.0035 \\
$p_{3}$ & 0.25 & 1.75 \\
\hline
\end{tabular}

${ }^{a}$ Adapted from Kushlan [1,2]. 
Table 4. The Lumped Mortality Parameters in Each Month for Two Functional Type Fish ${ }^{\mathrm{a}}$

\begin{tabular}{|c|c|c|}
\hline \multirow[b]{2}{*}{ Month } & \multicolumn{2}{|c|}{ Fish Functional Type } \\
\hline & Type 1: Small Fish & Type 2: Large Fish \\
\hline Jan. & $0.25 \sim 0.35$ & $0.05 \sim 0.3$ \\
\hline Feb. & $0.1 \sim 0.3$ & $0.01 \sim 0.2$ \\
\hline March & $0.1 \sim 0.25$ & $0.01 \sim 0.15$ \\
\hline April & $0.05 \sim 0.2$ & $0.005 \sim 0.1$ \\
\hline May & $0.1 \sim 0.35$ & $0.01 \sim 0.2$ \\
\hline June & $0.1 \sim 0.4$ & $0.01 \sim 0.45$ \\
\hline July & $0.25 \sim 0.45$ & $0.05 \sim 0.6$ \\
\hline Aug. & $0.3 \sim 0.52$ & $0.15 \sim 0.7$ \\
\hline Sept. & $0.4 \sim 0.6$ & $0.28 \sim 0.75$ \\
\hline Oct. & $0.45 \sim 0.6$ & $0.35 \sim 0.85$ \\
\hline Nov. & $0.2 \sim 0.35$ & $0.3 \sim 0.7$ \\
\hline Dec. & $0.1 \sim 0.3$ & $0.05 \sim 0.6$ \\
\hline
\end{tabular}

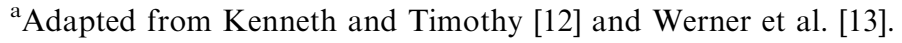

Table 5. Parameters Describing Movement Patterns, i.e., Probabilities of Reaching Pond During Dry Down or Moving from Pond to Marsh During Reflooding in Each Month for Two Functional Type Fish ${ }^{\mathrm{a}}$

\begin{tabular}{lcr}
\hline & \multicolumn{2}{c}{ Fish Functional Type } \\
\cline { 2 - 3 } Month & Type 1: Small Fish & Type 2: Large Fish \\
\hline Jan. & $0.7 \sim 0.9$ & $0.2 \sim 0.7$ \\
Feb. & $0.55 \sim 0.6$ & $0.3 \sim 0.4$ \\
March & $0.6 \sim 0.8$ & $0.2 \sim 0.3$ \\
April & $0.65 \sim 0.7$ & $0.4 \sim 0.6$ \\
May & $0.1 \sim 0.2$ & $0.2 \sim 0.3$ \\
June & $0.55 \sim 0.9$ & $0.3 \sim 0.6$ \\
July & $0.7 \sim 0.8$ & $0.5 \sim 0.9$ \\
Aug. & $0.8 \sim 0.9$ & $0.4 \sim 0.7$ \\
Sept. & $0.55 \sim 0.7$ & $0.3 \sim 0.5$ \\
Oct. & $0.6 \sim 0.9$ & $0.2 \sim 0.6$ \\
Nov. & $0.8 \sim 0.95$ & $0.6 \sim 0.8$ \\
Dec. & $0.8 \sim 0.9$ & $0.4 \sim 0.8$
\end{tabular}

${ }^{\mathrm{a} A d a p t e d ~ f r o m ~ M c I v o r ~ a n d ~ O d u m ~[14] ~ a n d ~ J o r d a n ~ e t ~ a l . ~[4] . ~}$

Trophic interactions parameters: Table 6 lists the parameters relating each fish functional type and its prey. These parameters imply that if all potential preys of a functional type are available in unlimited amounts the functional type would take prey in those proportions. Table 7 lists the initial biomass of lower trophic level and two functional type fish along with the parameters presented in Eq. [2]. 
Table 6. Parameters Describing Trophic Interactions ${ }^{\mathrm{a}}$

\begin{tabular}{lcc}
\hline & \multicolumn{2}{c}{ Fish Functional Type } \\
\cline { 2 - 3 } Parameter & Type 1: Small Fish & Type 2: Large Fish \\
\hline Periphyton & 0.54 & \\
Macrophytes & 0.24 & 0.06 \\
Detritus & 0.05 & 0.11 \\
Mesoinvertebrates & 0.17 & 0.83 \\
Macroinvertebrates & & \\
Fish functional type 1 & & \\
\hline
\end{tabular}

${ }^{a}$ Adapted and estimated from Patten [16].

Table 7. Initial Biomass per Square Meter of Trophic Levels and the Principle Parameters of Eq [2] Used in the Model Simulation

\begin{tabular}{ll}
\hline Parameter & Value \\
\hline$F_{L}(0)$ & $0.109 \mathrm{~g} \mathrm{~m}^{-2 \mathrm{a}}$ \\
$F_{S}(0)$ & $0.319 \mathrm{~g} \mathrm{~m}^{-2 \mathrm{a}}$ \\
$B_{I}(0)$ & $0.617 \mathrm{~g} \mathrm{~m}^{-2 \mathrm{~b}}$ \\
$B_{2}(0)$ & $3.15 \mathrm{~g} \mathrm{~m}^{-2 \mathrm{a}}$ \\
$B_{3}(0)$ & $2.25 \mathrm{~g} \mathrm{~m}^{-2 \mathrm{c}}$ \\
$B_{4}(0)$ & $0.065 \mathrm{~g} \mathrm{~m}^{-2 \mathrm{a}}$ \\
$B_{5}(0)$ & $0.88 \mathrm{~g} \mathrm{~m}^{-2 \mathrm{a}}$ \\
$a$ & $2.25 \mathrm{~d}^{-1 \mathrm{a}}$ \\
$b$ & $0.03 \mathrm{~d}^{-1} \mathrm{~g}^{-1 \mathrm{c}}$ \\
$c$ & $0.39^{\mathrm{b}}$ \\
$d$ & $0.14 \mathrm{~d}^{-1} \mathrm{~g}^{-1 \mathrm{a}}$ \\
$e$ & $0.254 \mathrm{~d}^{-1} \mathrm{~g}^{-1 \mathrm{~b}}$ \\
$f$ & $0.745 \mathrm{~d}^{-1} \mathrm{~g}^{-1 \mathrm{a}}$ \\
$g$ & $0.125 \mathrm{~d}^{-1} \mathrm{~g}^{-1 \mathrm{~b}}$ \\
$h$ & $0.355^{\mathrm{b}}$ \\
$j$ & $0.000825 \mathrm{~d}^{-1} \mathrm{~g}^{-1 \mathrm{~b}}$ \\
$j$ & $0.000425 \mathrm{~d}^{-1} \mathrm{~g}^{-1 \mathrm{~b}}$ \\
$k$ & $4.5 \mathrm{~d}^{-1} \mathrm{~g}^{-1 \mathrm{a}}$ \\
$m$ & $0.05 \mathrm{~d}^{-1 \mathrm{a}}$ \\
$\alpha$ & $0.07 \mathrm{~d}^{-1 \mathrm{a}}$ \\
\hline & $0.54 \mathrm{~d}^{-1 \mathrm{a}}$ \\
\hline
\end{tabular}

${ }^{\mathrm{a}}$ Estimated from Patten [16].

${ }^{\mathrm{b}}$ Estimated from Le Cren et al. [17].

${ }^{\mathrm{c}}$ Estimated from Gerking [18].

Water depth scenarios: Figure 2 shows three different water depth scenarios through a single year ranging from a scenario with a dry period of about five months (scenario A), a normal water level (scenario B), to a scenario where the spatial cell is flooded during the whole year (scenario C). To eliminate any effect of initial conditions on the fish populations, the 


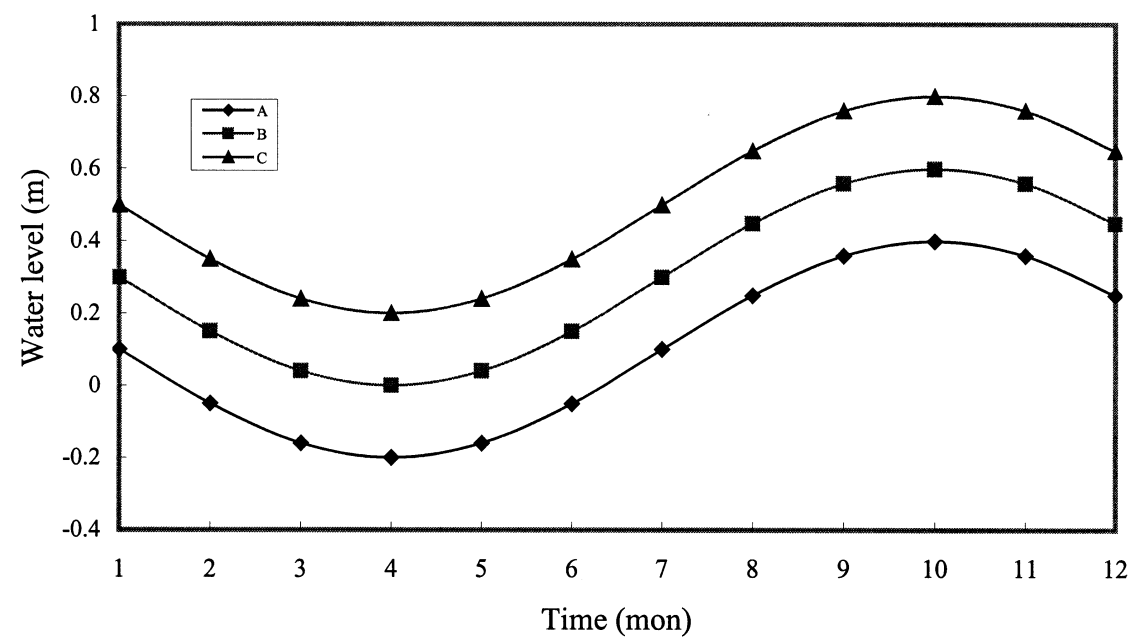

Figure 2. Three hypothetical water level scenarios for the studies spatial cell through the year where curve A represents a dry down; curve B, a normal water depth; and curve C, a flooding scenario.

simulation was extended for 10 years, with the same seasonal pattern of water depth repeated each year in a given simulation.

Drought scenarios: Figure 3 shows two different patterns of drought imposed on an otherwise continuously flooded cell. The shorter drought period (curve A) consisted of a small dry down in Year 7. The longer drought period (curve B) consisted of a drought period lasting from Years 5 to 7 , and large dry downs in the three succeeding years. Such prolonged droughts may be more common as a result of human modification of the system's hydrology.

Finally, the overall dynamic model reflects the trophic level interactions in that the small fish feed on the preys from lower trophic level web and the large fish feed almost exclusively smaller functional group, can be expressed as follows based on Table 6,

$$
\begin{aligned}
\frac{d F_{L}(t)}{d t}= & 0.06 B_{4}(t)+0.11 B_{5}(t)+0.83 F_{S}(t)-0.05 F_{L}(t) \\
\frac{d F_{S}(t)}{d t}= & 0.54 B_{2}(t)+0.24 B_{3}(t)+0.05 B_{4}(t)+0.17 B_{5}(t)-0.83 F_{S}(t) \\
& -0.07 F_{S}(t),
\end{aligned}
$$

The system of Eqs. [5], [8], and [9] is solved numerically by using the subroutine ODE45 based on the $4^{\text {th }}$-order Runge-Kutta method of MATLAB Version 5.1 and done in double precision with FORTRAN 90. The algorithm is stable provided the error and the convergence criteria are carefully monitored. 


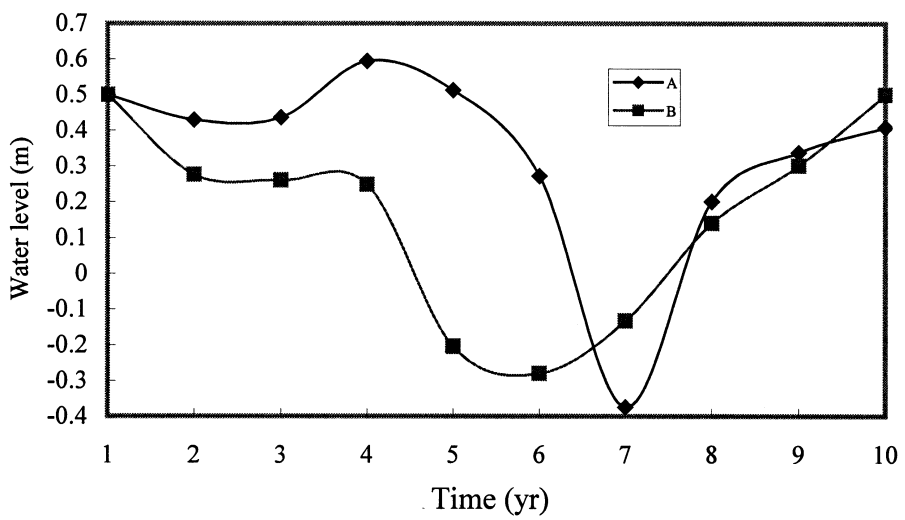

Figure 3. Water levels in spatial cell for two assumed drought scenarios where curve A represents shorter drought period, whereas the longer drought period represented by curve B.

\section{Simulation Results}

Figures 4-6 show the model predictions of number densities and biomass (fish $\mathrm{m}^{-2}$ and $\mathrm{g} \mathrm{m}^{-2}$ ) of the two functional type fish throughout the year for each of the scenarios corresponding to hydroperiod scenarios A, B, and C of Figure 2. Figure 4 shows the population density for hydroperiod A (dry down scenario) reach a maximum of only slightly more than $0.082 \mathrm{fish} \mathrm{m}^{-2}$ $\left(24.59 \mathrm{~g} \mathrm{~m}^{-2}\right)$ and slight more than $0.21 \mathrm{fish} \mathrm{m}^{-2}\left(1.03 \mathrm{~g} \mathrm{~m}^{-2}\right)$, for large and small fish, respectively. Apparently, a flooded period of only seven or eight months is not sufficient for large population growth. A strong periodicity is shown in the intermediate scenario B (normal water level), with maximum population densities toward the end of the flooded period of more than 0.16 fish $\mathrm{m}^{-2}\left(47.04 \mathrm{~g} \mathrm{~m}^{-2}\right)$ and 0.34 fish m$^{-2}\left(1.7 \mathrm{~g} \mathrm{~m}^{-2}\right)$, respectively for large and small fish (Figure 5). When the cell is flooded continuously, the populations of the two functional type fish fluctuate between about 0.1 and $0.2 \mathrm{fish} \mathrm{m}^{-2}$ (Figure 6). The reason for the seasonal changes in this case is that the lower trophic levels are undergoing seasonal variations. This is the same result obtained by Kushlan $(1,2)$. The densities, however, follow the same seasonal pattern of increase through the period of cell flooding.

In the second simulations were performed in which large fish were removed from the simulations altogether to see whether that had a significant effect on the predicted population of small fish. Figure 7 shows that the biomass of small fish increases from 7.82 to $100.66 \mathrm{~g} \mathrm{~m}^{-2}$, whereas the

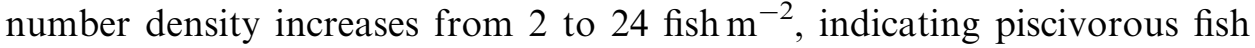
appear to have the significant regulatory effect on smaller fish numbers.

In the third simulation experiment, the spatial cell was subjected to a situation in which hydrology changed from year to year. The purpose of this experiment was to determine the resilience of the small fish population, i.e., 

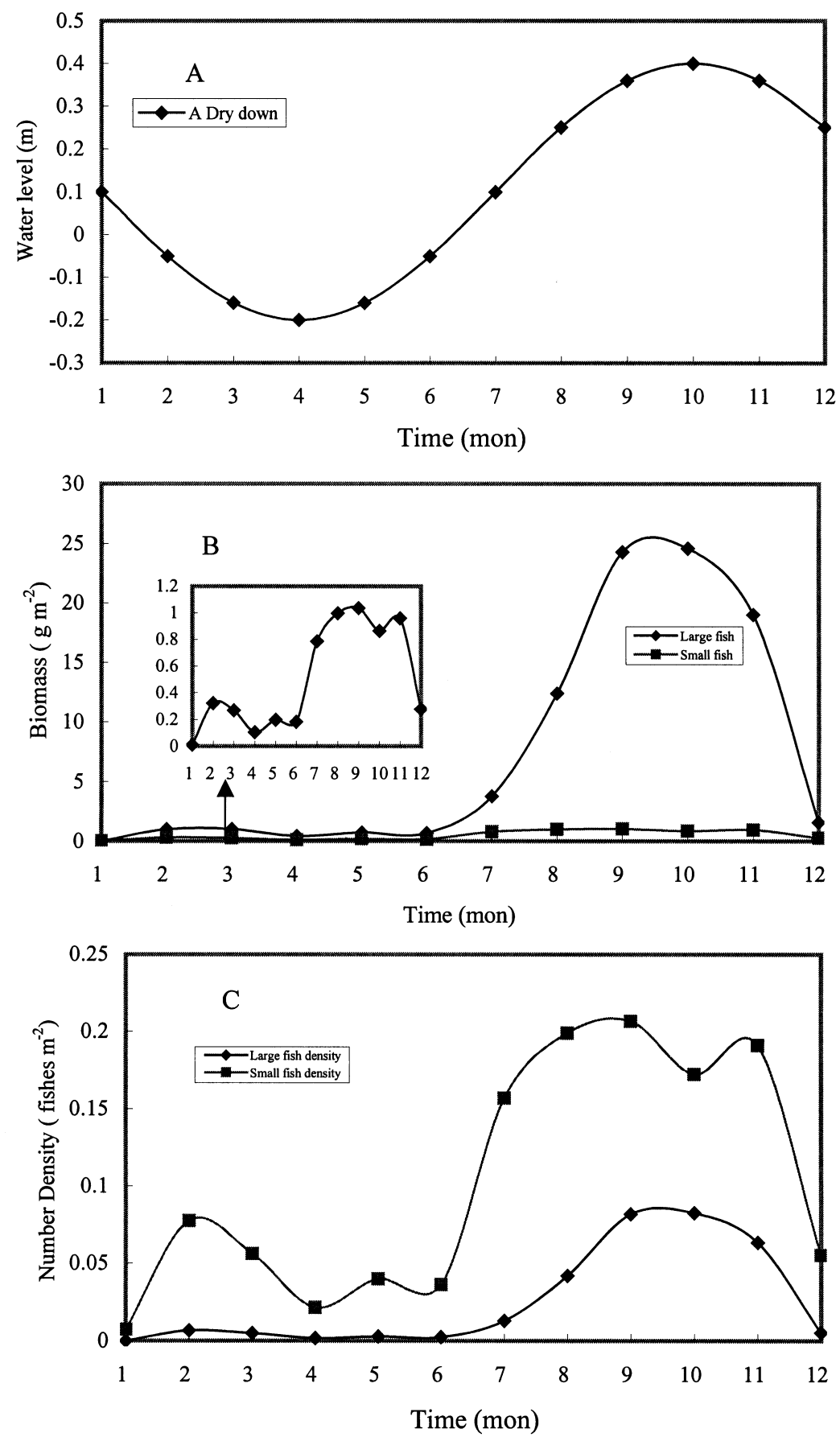

Figure 4. Biomass and densities of the two functional type fish simulated through the year corresponding to hydroperiod scenario A of Figure 2. 


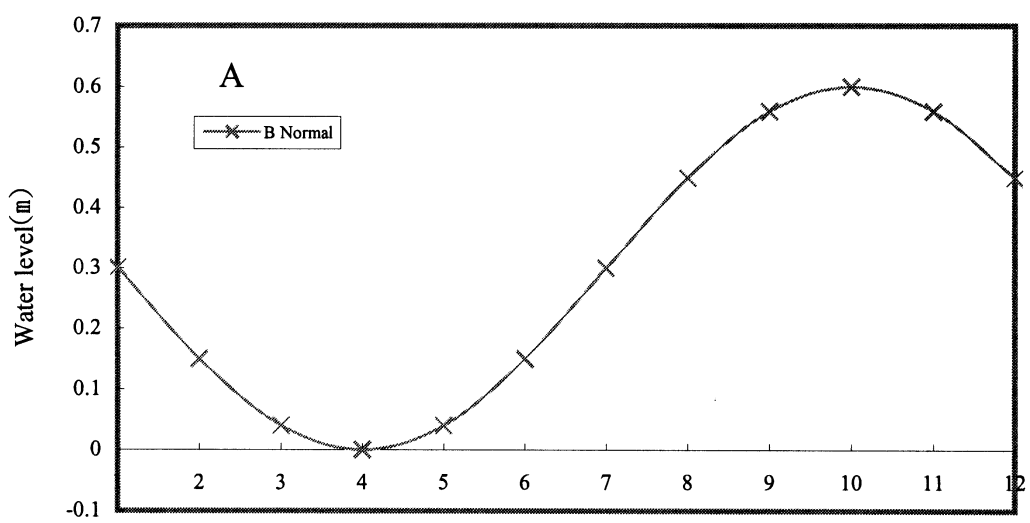

Time (mon)
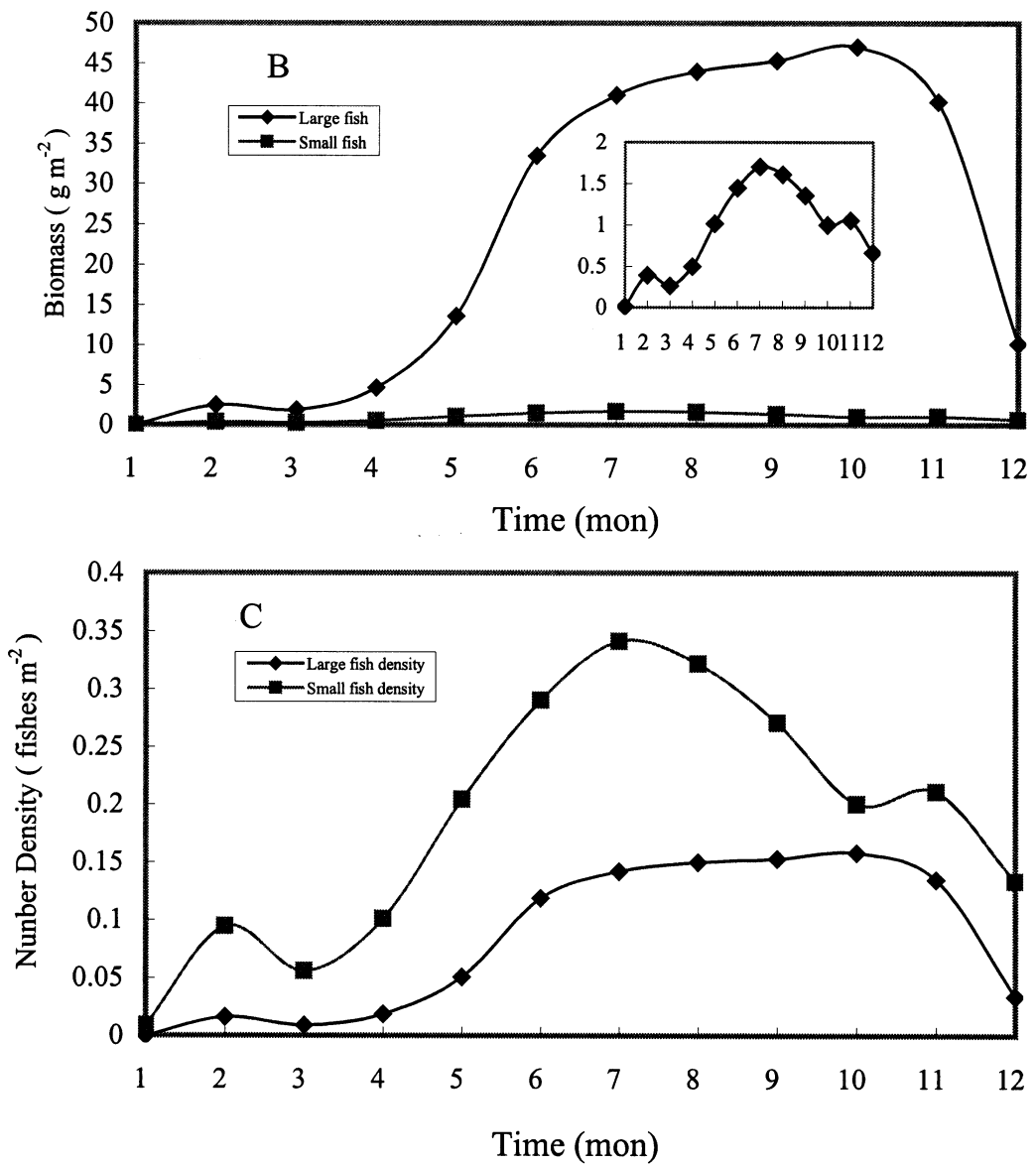

Figure 5. Biomass and densities of the two functional type fish simulated through the year corresponding to hydroperiod scenario B of Figure 2. 

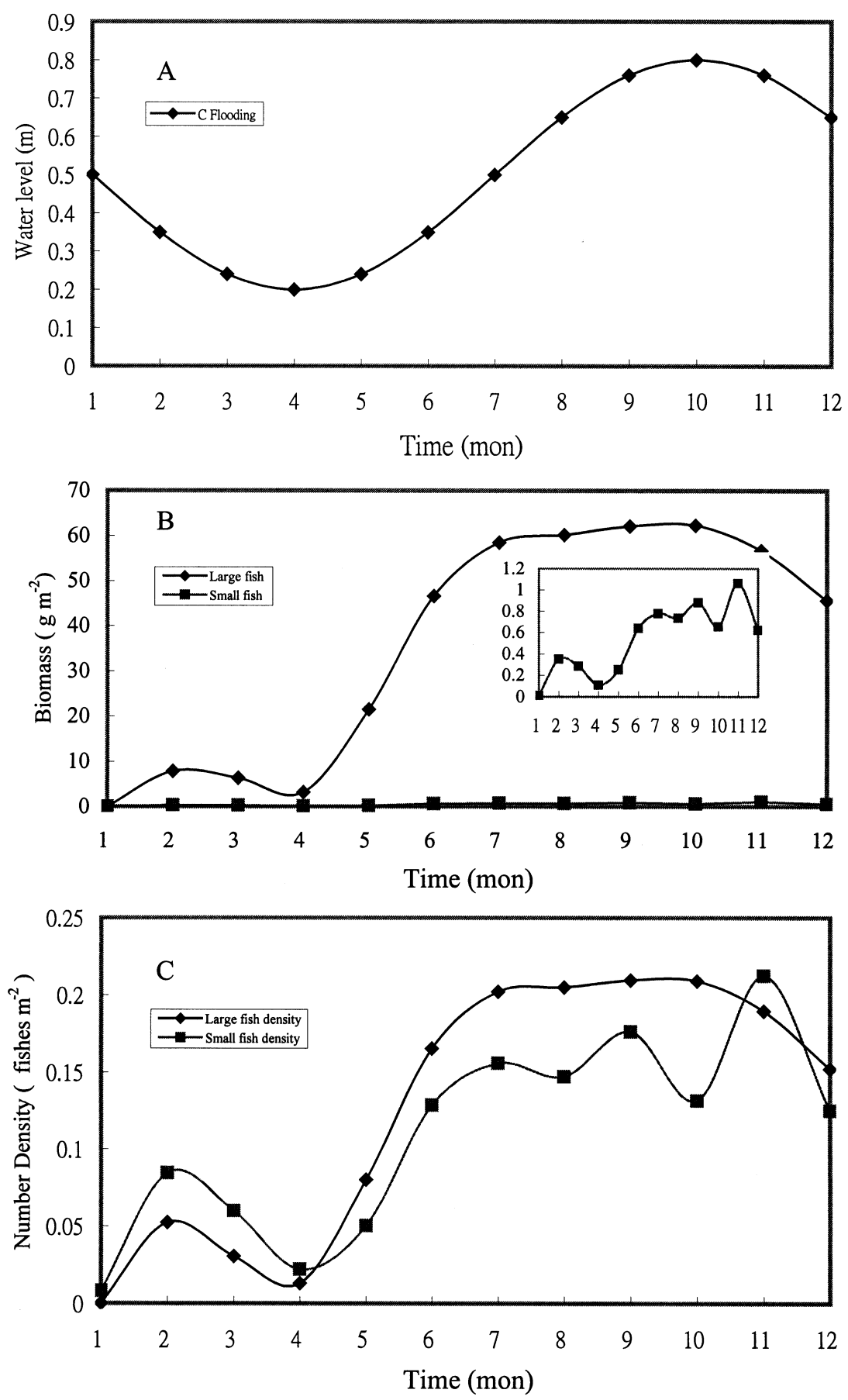

Figure 6. Biomass and densities of the two functional type fish simulated through the year corresponding to hydroperiod scenario $\mathrm{C}$ of Figure 2. 

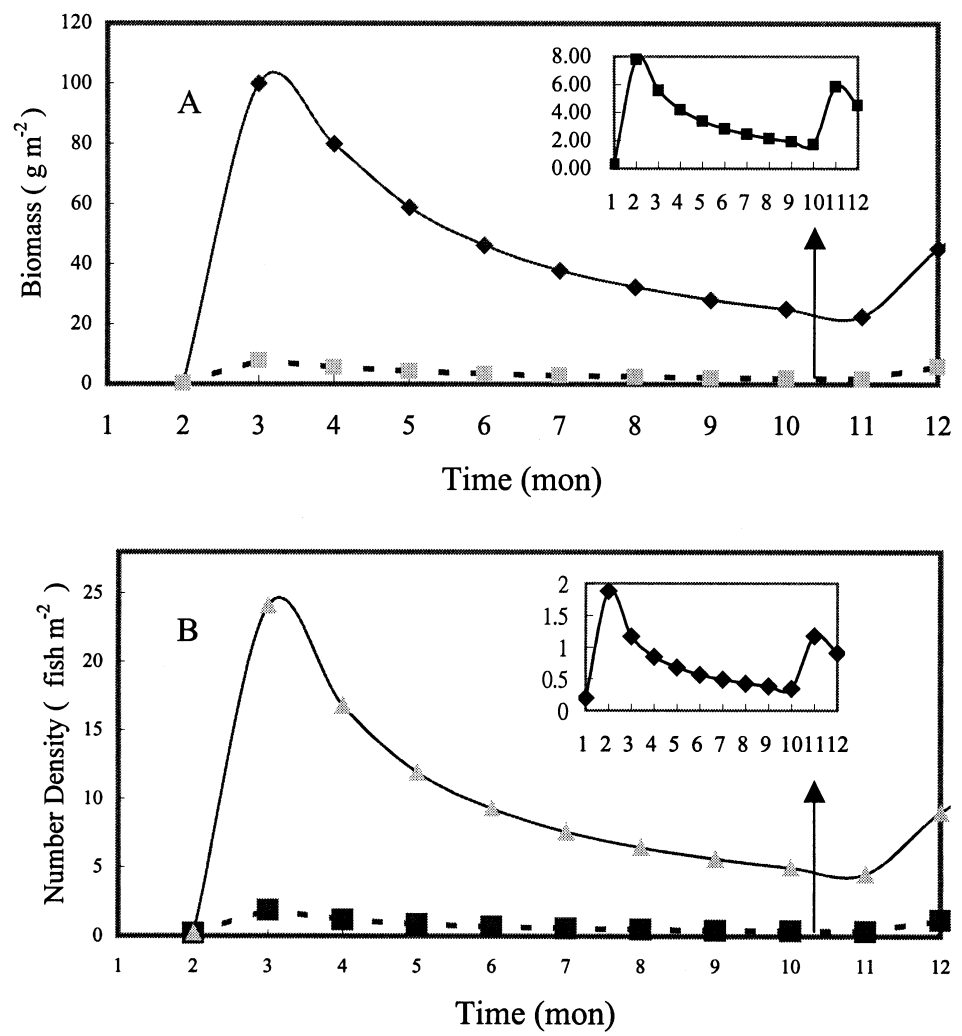

Figure 7. Biomass and densities of small functional type fish when the large fish were removed from the simulation (solid lines). Dotted lines represent the large fish still exist in the cell.

to determine how rapidly it could return to previous high levels following droughts of different levels of severity. Simulations over 10-year periods were performed under two different scenarios that shown in Figure 3. In the drought experiment depicted in Figures 8 and 9, the population subjected to a 3 -year drought declines far below that subjected to only 1-year drought, though it does not go to extinction. This is shown in Figures 8(C) and 9(C), where the natural $\log$ of the populations plotted. The population subjected to a large drought is smaller than the other population by a magnitude of about $10^{2}$ at Years 6 and 7. Figures $8(\mathrm{C})$ and $9(\mathrm{C})$ also indicate that both populations recover to their baseline levels for flooded conditions within about two years.

The system studies in this paper regarding fish in a freshwater marsh that undergoes periodic flooding and drying is conceptually simple. During periods of flooding, populations of small fish invade the wetlands from ponds and other refuges and increase in size. The growth of the small fish type population continues until one of the following occurs: (i) resources in the flooded marsh become limiting, (ii) populations of piscivorous fish or other 

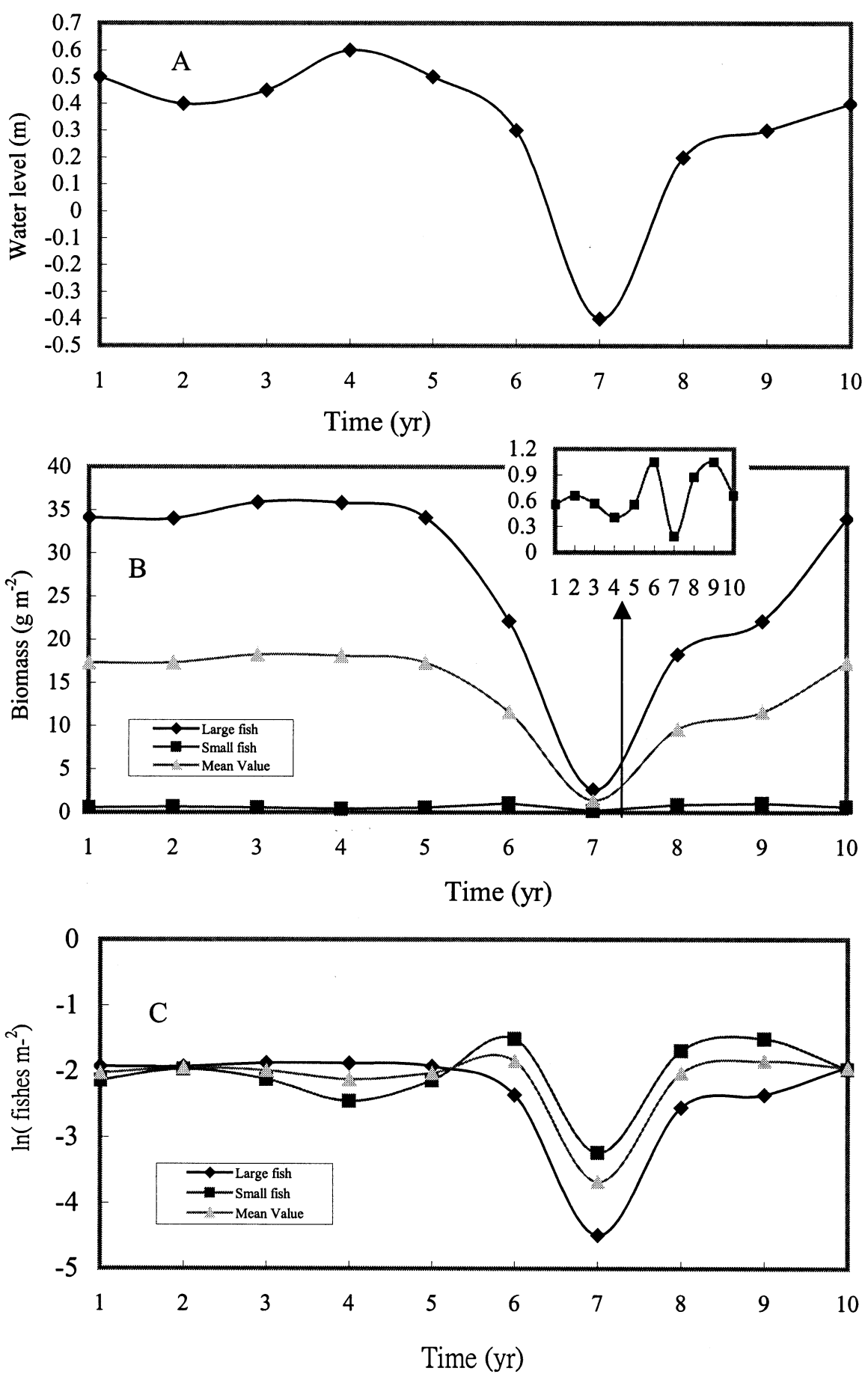

Figure 8. Biomass and natural logarithm of densities of two functional type fish simulated through 10 years period corresponding to drought scenario A of Figure 3. 

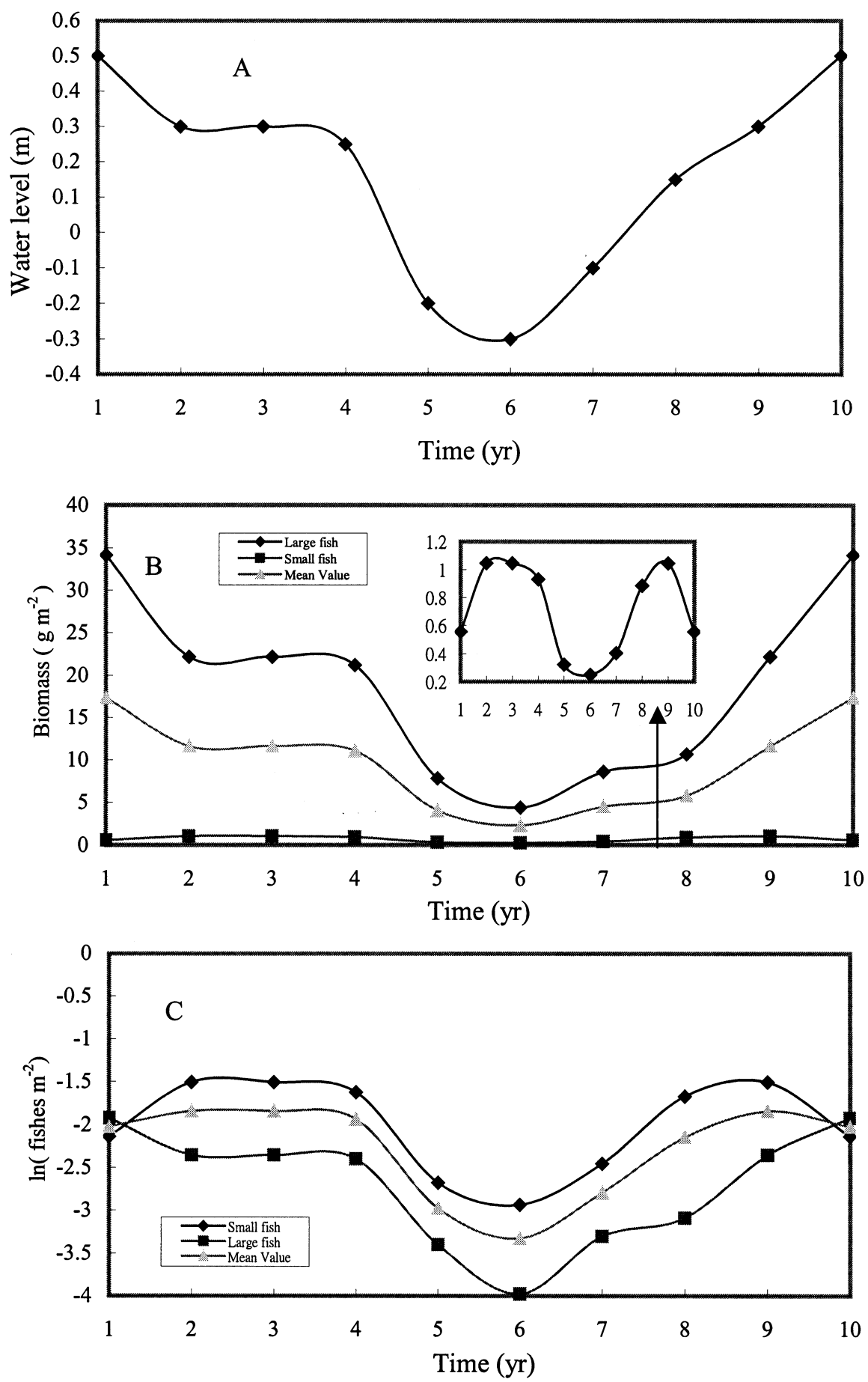

Figure 9. Biomass and natural logarithm of densities of two functional type fish simulated through 10 years period corresponding to drought scenario B of Figure 3. 
predators increase and control the small fish, or (iii) the next dry down of the marsh occurs. During dry downs, the fish retreat to ponds or other depressions.

The disadvantage of this conceptual model is that many field data are needed to validate it. For example, knowledge of the microtopography of the spatial cell is essential, because it determines the amount of refuge area that remains at decreasing water depths as the marsh dries. The fraction of fish able to find refuges also had to be estimated. The life-cycle characteristics of the small fish had to be known to predict the speed of recovery of the populations following reflooding. The resource base of the small fish had to be modeled. Similar characteristics of piscivorous fish and their ability to feed on smaller fish in the complex marsh environment had to be quantified as well.

Beyond these difficult assumptions that were incorporated into the model are aspects of the system that we did not even attempt to take into account. It is possible that, for example, dry downs have broader effects than simply reducing the fish populations. The length and magnitude of a dry down may have an effect on lower trophic level productivity during the next period of flooding. We also simplified the system to small planktivorous and large piscivorous fish interacting with a simple food web, ignoring other aspects of the food web. We believe that the model makes predictions that may be useful, particularly for roughly predicting the amount of biomass that may become available to higher trophic levels, in particular, to wading birds, during the marsh hydrologic cycle.

The model makes three further predictions that appear to us to be fairly robust in the model system. First, there appears to be a threshold of about 9-10 months in the length of the hydroperiod. If the hydroperiod is less than this, the small fish population stays small, no more than a few fish per square meter. For longer hydroperiods, the fish population can reach levels of 6 to 8 fish $\mathrm{m}^{-2}$ by the end of the hydroperiod roughly indicating what the population would be under continuously flooding. The second prediction is that the large, piscivorous fish have a significant impact on small fish populations in the marsh. The third prediction is that the repopulation of the small fish following a dry down (even a prolonged dry down) occurs within two years.

Although this model is still in the early stages of development, we feel that it already may be of use to resource managers. One important use is to future research. From the results of the simulations presented in this paper, we have already identified and initiated several new lines of research. Clearly there is limited time and money, and all areas cannot be monitored. It may be equally useful to run various model experiments that can determine the relative important of predation and annual water level fluctuations within the region. Models allow us to isolate factors in model experiments that may not be possible to control adequately in the field and laboratory. Finally this model can be used to run various scenarios with alternate management and 
restoration strategies; this is especially relevant in areas where protection of wading birds has been considered as a management option.

\section{CONCLUSIONS}

The type of pulsed hydroperiod wetlands simulated here is an important generic type that occurs in many places especially in the tropics and subtropics. The hydroperiod is a key feature that can lead to the seasonal expansion and growth of prey populations and their subsequent concentration for higher trophic levels. Changes in the nature of the timing, extent and duration of flooding, may affect this process of collection and concentration of biomass.

The results of this study have obvious implications for the conservation of species, such as wading birds, that depend on high concentrations of prey produced in fluctuated hydroperiod wetlands. Humans are manipulating the water in many such systems for urban and agricultural use as well as for flood control. A result of such manipulations is that hydroperiods will be changed. The effects of such changes can be devastating for wildlife and need to be understood better and predicted where possible. Simulation modeling is one tool that can be used to elucidate these effects. Moreover, models can be used to predict long-term effects of different scenarios that may not be readily tested in the field or experimentally. In this case, modeling proved to be the most useful approach as predicted recovery times were long.

\section{ACKNOWLEDGMENTS}

The authors wish to acknowledge the financial support of the ChungCheng Agricultural Science and Social Welfare Foundation of Republic of China.

\section{REFERENCES}

1. Kushlan, J.A. Environmental stability and fish community diversity. Ecology 1976, 57, 821-825.

2. Kushlan, J.A. Population fluctuations of Everglades fishes. Copeia 1980, 4, 870-874.

3. Capone, T.A.; Kushlan, J.A. Fish community structure in dry-season stream pools. Ecology 1991, 72, 983-992.

4. Jordan, F.; Babbitt, K.J.; McIvor, C.C. Seasonal variation in habitat use by marsh fishes. Eco. Freshwater Fish 1998, 7, 159-166.

5. Snodgrass, J.W.; Jagoe, C.H.; Bryan, A.L.; Brant, H.A.; Burger, J. Effects of trophic status and wetland morphology, hydroperiod, and water chemistry on mercury concentrations in fish. Can. J. Fish Aqua. Sci. 2000, 57, 171-180. 
6. Lorenz, J.J. The response of fishes to physicochemical changes in the mangroves of northeast Florida Bay. Estuaries 1999, 22, 500-517.

7. Snodgrass, J.W.; Komoroski, M.J.; Bryan, A.L.; Burger, J. Relationships among isolated wetland size, hydroperiod, and amphibian species richness: Implications for wetland regulations. Conserv. Biol. 2000, 14, 414-419.

8. Nuttle, W.K. Measurement of wetland hydroperiod using harmonic analysis. Wetlands 1997, 17, 82-89.

9. Murray, J.D. Mathematical Biology; Springer-Verlag: New York; 1989.

10. Shao, K.C. Changes of Bioresource in the Kuandu Natural Reservation and the Natural Park, Final Report; Bureau of Construction, Taipei City Government: Taipei, Taiwan, Republic of China, 1999; 13-17.

11. Gamito, S. Growth model and their use in ecological modeling: an application to a fish population. Eco. Modelling 1998, 113, 83-94.

12. Kenneth, L.H. Jr.; Timothy, A.T. Experiments on predator-prey interaction in vegetatied aquatic habitats. J. Exp. Mar. Biol. Ecol. 1988, 53, 125-134.

13. Werner, E.E.; Gilliam, J.F.; Donald, J.H.; Mittelbach, G.G. An experimental test of the effects predation risk on habitat use in fish. Ecology 1983, 64, $1540-1548$.

14. McIvor, C.C.; Odum, W.E. Food, predation, risk, and microhabitat selection in a marsh fish assemblage. Ecology 1988, 69, 1341-1351.

15. Weatherley, A.H. Growth and Ecology of Fish Populations; Academic Press: London; 1972.

16. Patten, B.C. Systems Analysis and Simulation in Ecology; Academic Press: London; 1975.

17. Le Cren, E.D.; Lowe-McConnel, R.H. The Functioning of Freshwater Ecosystems; University of Cambridge Press: London; 1980.

18. Gerking, S.D. Ecology of Freshwater Fish Production; John Wiley \& Sons: New York, 1978.

Received December 8, 2000 


\section{Request Permission or Order Reprints Instantly!}

Interested in copying and sharing this article? In most cases, U.S. Copyright Law requires that you get permission from the article's rightsholder before using copyrighted content.

All information and materials found in this article, including but not limited to text, trademarks, patents, logos, graphics and images (the "Materials"), are the copyrighted works and other forms of intellectual property of Marcel Dekker, Inc., or its licensors. All rights not expressly granted are reserved.

Get permission to lawfully reproduce and distribute the Materials or order reprints quickly and painlessly. Simply click on the "Request

Permission/Reprints Here" link below and follow the instructions. Visit the U.S. Copyright Office for information on Fair Use limitations of U.S. copyright law. Please refer to The Association of American Publishers' (AAP) website for guidelines on Fair Use in the Classroom.

The Materials are for your personal use only and cannot be reformatted, reposted, resold or distributed by electronic means or otherwise without permission from Marcel Dekker, Inc. Marcel Dekker, Inc. grants you the limited right to display the Materials only on your personal computer or personal wireless device, and to copy and download single copies of such Materials provided that any copyright, trademark or other notice appearing on such Materials is also retained by, displayed, copied or downloaded as part of the Materials and is not removed or obscured, and provided you do not edit, modify, alter or enhance the Materials. Please refer to our Website User Agreement for more details.

\section{Order now!}

Reprints of this article can also be ordered at http://www.dekker.com/servlet/product/DOI/101081ESE100104872 